\title{
Phytochemical Profiling of Medicinal Plants Extracts and Their Antioxidant and Anticancer Potentialities Against Human Liver Cancer (Hep G2) Cell Lines
}

\author{
NUSRAT SHAFIQ ${ }^{1}$, FARAH YASMIN ${ }^{1}$, SADIA NOREEN ${ }^{2}$, ALINA SHAHZAD ${ }^{1}$, \\ ZILL-I-HUMA NAZLI ${ }^{1}$, SHAGUFTA PARVEEN ${ }^{1}$, BASHARAT ALI ${ }^{3}$, ZAHEER AHMAD $^{4}$, \\ MARYAM RASHID ${ }^{1}$, MUHAMMAD BILAL ${ }^{5 *}$ \\ ${ }^{1}$ Department of Chemistry, Government College Women University, Faisalabad-38000, Pakistan \\ ${ }^{2}$ Department of Biochemistry, Government College Women University, Faisalabad-38000, Pakistan \\ ${ }^{3}$ Department of Chemistry, Khawja Fareed University of Engineering and Information Technology, Rahim Yar Khan, \\ Pakistan \\ ${ }^{4}$ Department of Chemistry, University of Wah, Wah Cannt., Pakistan \\ ${ }^{5}$ School of Life Science and Food Engineering, Huaiyin Institute of Technology, Huaian 223003, China
}

Abstract. Although Pakistan is stacked with enormous varieties of medicinal plants, only a little proportion of these plants has been evaluated for their medicinal and therapeutic properties. Herein, four indigenous medicinal plants Citrus sinenesis, Citrus paradiasii, Moringa olifera, and Hibiscus rosa-sinenesis were collected and subjected to phytochemical analyses to scrutinize the presence of secondary metabolites. Qualitative analysis showed the presence of an array of secondary metabolites in the selected plants, which were further corroborated by high-performance liquid chromatography. Results revealed the presence of 33.24, 21.04, 15.2 ppm gallic acid in methanol, ethyl acetate and nhexane fraction of $C$. sinensis peels extract, respectively. C. paradaissi peels consist of 24.06, and 18.24 ppm of gallic acid and caffeic acid, respectively, in methanol and chloroform fractions, whereas its methanolic seeds extract contain caffeic acid as a major component (10.63 ppm). H. rosa-sinenesis has shown p-coumaric acid, caffeic acid, and gallic acid at 35.26, 15.04, and 11.4 ppm, respectively. M. olifera contained 3.24 ppm gallic acid in pods extract while stems and leaves extract contain a very low amount. Anticancer profile evinced that Citrus sinensis extract showed the highest percent inhibition (142.746\%) of human liver cancer (Hep G2) cell lines followed by H. rosa-sinensis (132.49\%), C. paradaisii $(82.39 \%)$ and $M$. olifera (68.0\%). The determined $I_{50}$ values for antioxidant activity were C. sinenesis $\left(I C_{50}=0.49 \mathrm{mM}\right)$, C. paradaisii $\left(I C_{50}=0.43 \mathrm{mM}\right)$, M. olifera $\left(I_{50}=0.42 \mathrm{mM}\right)$ and $\mathrm{H}$. rosasinensis $\left(I C_{50}=0.41 \mathrm{mM}\right)$. Conclusively, the selected plants could be an effective alternative and deliverable chemical therapeutic to the pharmaceutical industry due to their excellent biological effects.

Keywords: Medicinal plants, Phytoconstituents, Flavonoids, Antioxidant activity, Anticancer, Cytotoxicity

\section{Introduction}

Fruits and vegetables are important for human life because their persistent utilization reduces the risk of many incurable diseases. With the advancements in technologies making life easier and facile, there is an increasing trend in the risk of stress-related diseases. Therefore, it is essential to take a healthy and natural diet. To cover this need, worldwide, intake of fruits, vegetables, plant-based foods, and nutrientrich plant products has been focused [1-5]. Nevertheless, the utilization of proper diet (a complex of vegetable, fruits, and nutritional juices) is not enough to prevent chronic diseases because a specific diet only provides more than 25,000 bioactive constituents. Among these, many are related to modification causing in processes of these chronic diseases. Thus, it is of paramount significance to develop biodrugs based on food and dietary products for the betterment of human health, which is only possible through a complete understanding of the complex relationship of food, vegetables, fruits, plant-products

*email: bilaluaf@hotmail.com; bilaluaf@hyit.edu.cn 
to cure diseases. According to the recommendation of nutritionist and biologist, food-based drugs have synergic and additive effects, which are necessary to cover health benefits and maintain human health. Therefore, it is a better approach by researchers and pharmacists around the world to design and develop food-based strategies to derive bio-drugs for health improvement. Mostly, food constitutes, and bioactive reagents are obtained from plants by extraction, known as phytoconstituents. These phytochemicals are reduced products of plants acting as antioxidants and produced as defense tools in response to the environmental stress and conditions in which the plants exist (Figure S1). As anti-oxidants, these bioactive constituents act as an inhibitor of free radicals like reactive oxygen and nitrogen species, which accelerate the chronic diseases [6]. From the beginning of life, natural products have been serving as excellent sources of novel drugs, which have proven as an inspiration and lead compounds for the synthesis of natural as well as non-natural compounds. It is important to introduce new pharmacological sources to scientific and social communityy [7]. Natural products are always acting as a supplier of bioactive scaffolds reservoir that has demonstrated significant avenues for the treatment of human diseasess [8]. Increasing interest in the use of medicinal plants and plant-derived drugs is due to their emerging effects in the maintenance of human health. It has been observed that the drugs derived from natural products are less toxic and free from adverse effects [9]. Keeping all beneficial properties in mind, the local flora of Pakistan was explored to identify their constituents to derive drugs and provide cost-effective, cheap, and promising remedies to treat diseases.

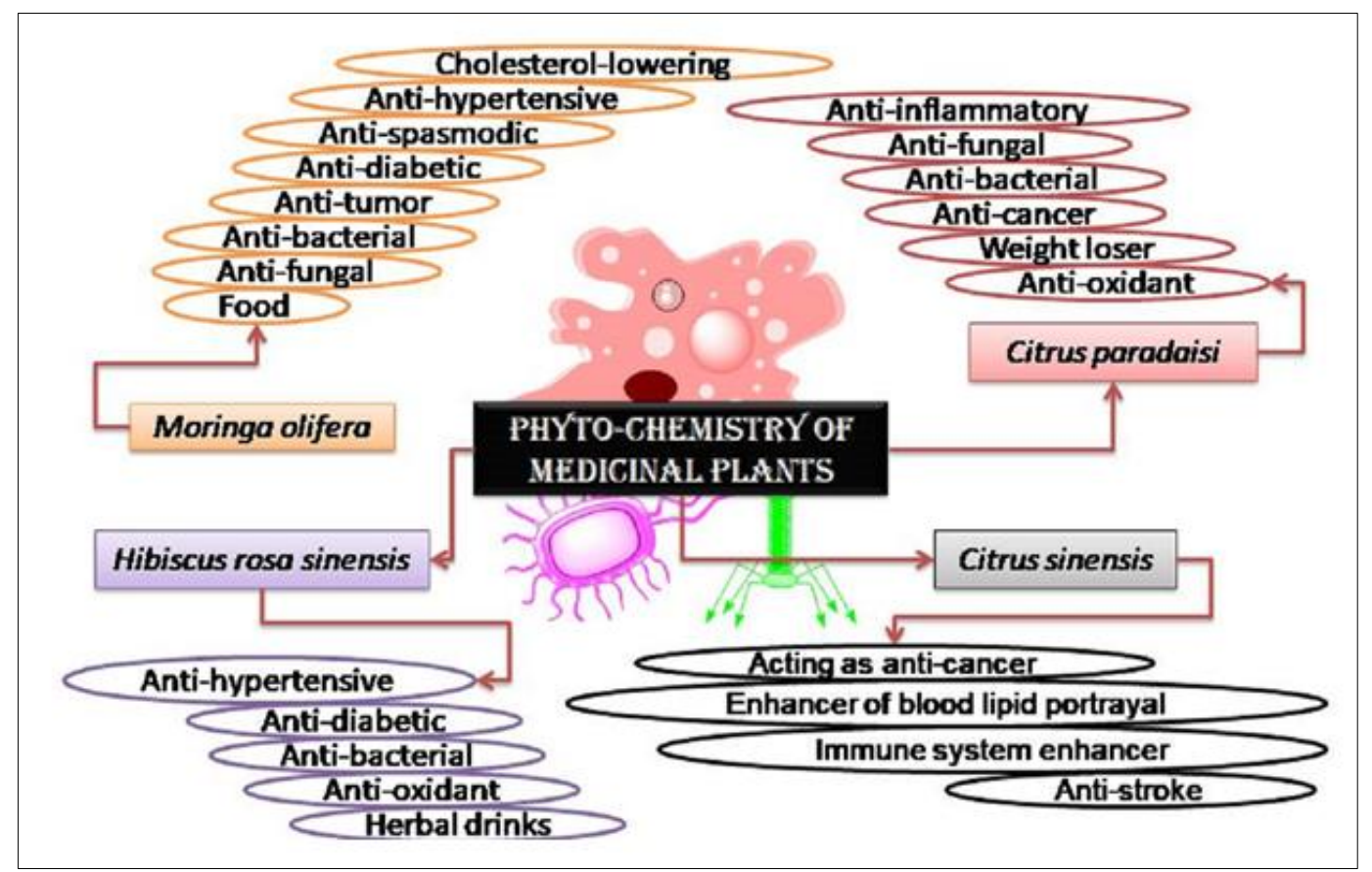

Figure 1. Biological applications of selected plants (Citurs sinenesis, Citrus paradaisiis, Moringa olifera, Hibiscus rosa-sinenesis

Citrus belongs to the family Rutaceae and is the most admired and favored fruit crop. The undeveloped peels of Citrus sinensis are capable of acting as a chemotherapeutic mean. Hesperidin, a $C$. sinensis flavonoid, exhibits potential stability on the bone condition and their metabolism. It is demonstrated that many types of cancers like colorectal, stomach, and esophageal can be retarded by $C$. sinensis fruit. Citrus sinensis fruit also enhances the blood lipid profile and anti-stroke action [10]. Moringa olifera, locally called as drumstick-tree or horseradish tree, and its different parts are used as food since ancient times. Traditional medicine systems used this plant to cure different diseases like ulcers, wound information, heart disorders, cancer, obesity, liver problems [11]. Different parts of the plant have been evaluated for their potential as therapeutics and observed to exhibit anti-hypertensive, anti-tumor, anti-inflammatory, anti-ulcer, anti-spasmodic, cholesterol-lowering, anti-diabetic, antiRev. Chim., 72(1), 2021, 99-109 
bacterial, and anti-fungal activities [12]. Citrus paradisi (commonly called grapefruit) is the second most worldwide used citrus crop [13]. Natural bioactive flavonoids reveal the antioxidant action and these flavonoids are present in higher amounts in the peels of $C$. sinensis. It has been utilized in various therapies as weight loss and immune system enhancement [14]. Traditionally, it has used as an antibacterial, anti-fungal, anti-inflammatory, antioxidant, and anticancer agent in the folk medicine system. Moreover, with health awareness and rising demand for anti-aging products, grapefruit has been used to clear oil from skin and acne issues [13]. A plant belongs to the genus Hibiscus is famous for its use in traditional medicines known as Hiboscus sabdariffa L. It has been used as food and herbal medicines, as well as, in herbal drinks, hot and cold drinks. Its extracts find use as antibacterial, antidiabetic, anti-oxidant, and antihypertensive agents (Figure 1) [15].

A large variety of phytochemicals is present in nature, and many of these phytochemicals possess medicinal and health beneficial properties. Many components are present in plant extract that manifest the physiological and medicinal actions. Many biological properties are also exhibited by these components such as anti-fungal, anti-apoptosis, anti-inflammation, anti-microbial, anti-urease, anticarcinogen, anti-bacterial, anti-oxidant, and anti-aging etc. [16]. Parasitic infections, which generated due to viruses, fungi, bacteria, and others, were treated for thousands of years by medicinal plants and their products. Recently, a number of synthetic and semi-synthetic drugs have been synthesized using these plants [16]. Different parts of these plants like flowers, seeds, leaves, roots, barks, and fruits have been exploited to cure various diseases and disorders. The oils extracted from medicinal plants have also been tested for their activity against pests, bacteria, fungi, insects and other microorganisms [17]. Therefore, in this study, indigenous medicinal plants $C$. sinenesis, $C$. paradiasii, $M$. olifera, and $H$. rosasinenesis were subjected to phytochemical analyses to scrutinize their bioactive constituents. Moreover, anticancer and antioxidant activities were also investigated to appraise their therapeutic potentialities.

\section{Material and methods}

\subsection{Plant materials and preparation of extracts}

All selected plants $C$. sinenesis, $C$. paradaisii, $H$. rosa-sinensis, and $M$. olifera were collected locally from different regions of Faisalabad. The selected plants were identified by Dr. Fouzia Shakoor, Department of Botany, The Government College Women University, Faisalabad. The collected plants were dried under shade and ground to a fine powder. The powdered material of the plant was extracted with water, chloroform, methanol, petroleum, and ethyl acetate. For each plant extract, powdered plant material was soaked in respective solvents for $24 \mathrm{~h}$ to obtain all polar and non-polar compounds. The extracts were evaporated under reduced pressure by a rotary evaporator.

\subsection{Qualitative and phytochemical analysis by HPLC}

Preliminary analysis of prepared plant extracts was carried out by performing different tests (Mayer's Test, Wagner's test, Ninhydrine, Molisch's test, Benedict's test, Spot test, Saponification test, Borntrager's test, Legal's test, Ferric chloride test, Gelatin test, Lead acetate test, Alkaline test, Magnesium \& Hydrochloric acid test, Libermann-Burchard's test, Millon's test, Biuret test, Shinoda test, Keller-Kiliani Test, and Salkowski's test) $[18,19]$ to confirm the presence of secondary metabolites in the selected plants (Table 1). For quantitative analysis, the prepared extracts of selected plant species were subjected to HPLC to estimate the number of different phytochemicals. To perform a quantitative analysis of different solvent fractions of selected plants, their solutions were prepared. About $0.1 \mathrm{~g}$ of each extract (petroleum, chlororform, ethyl acetate, water, and methanol) was taken in a conical flask $(100 \mathrm{~mL})$. Then about $5 \mathrm{~mL} \mathrm{HCl}$ and $10 \mathrm{~mL}$ distilled water was added, followed by the addition of 15 $\mathrm{mL}$ methanol. After mixing all, the mixture was put into an oven for $1.5 \mathrm{~h}$ and then subjected to HPLC for analysis. For HPLC analysis, sample preparation was done according to the method described in literature. The separation of plant samples on gradient HPLC was performed using shim-pack CLC-ODS (C18), $25 \mathrm{~cm} 4.6 \mathrm{~mm}, 5-\mu \mathrm{m}$ column. The chromatographic separation was carried out using a mobile phase gradient: $\mathrm{A}\left(\mathrm{H}_{2} \mathrm{O}\right.$ : Acetic acid 94:6, $\left.p \mathrm{H}=6\right)$, $\mathrm{B}$ (Acetonitrile 100\%) 0-15 $\min =15 \% \mathrm{~B}, 15-30$ 
$\min =45 \% \mathrm{~B}, 30-45 \mathrm{~min}=100 \% \mathrm{~B}$ with $1 \mathrm{~mL} / \mathrm{min}$ flow rate using UV-visible detector at $280 \mathrm{~nm}$ wavelength at room temperature. The identification of each compound was established by comparing the retention time and UV-Vis spectra of the peaks with that obtained by the injection of standards. The quantification was performed by external calibration with standards.

Table 1. Tests performed for the qualitative analysis of secondary metabolites in selected medicinal plants

\begin{tabular}{|c|c|c|c|c|}
\hline $\begin{array}{l}\text { S. } \\
\text { No. }\end{array}$ & $\begin{array}{c}\text { Class } \\
\text { of compounds }\end{array}$ & Tests performed & Observations & References \\
\hline 1 & Tannins & $\begin{array}{l}2 \mathrm{~mL} \text { of plant extract was added to } 2 \mathrm{~mL} \text { of distill water and } \\
\text { then added } 2-3 \text { ferric chloride }(5 \%) \text { drops. }\end{array}$ & Precipitates of green color & $29-30$ \\
\hline \multirow[t]{5}{*}{2.} & \multirow[t]{5}{*}{ Flavonoids } & $\begin{array}{l}1 \mathrm{~mL} \text { of solution of }(10 \%) \text { lead tetra-acetate was mixed to } \\
\text { the } 1 \mathrm{~mL} \text { of plant extract. }\end{array}$ & Yellow color & 30 \\
\hline & & $\begin{array}{l}\text { From } 2 \% \mathrm{NaOH} \text { solution just } 2 \mathrm{~mL} \text { was added to the crude } \\
\text { extract }\end{array}$ & $\begin{array}{l}\text { Deep Yellow coloration, } \\
\text { which disappears on } \\
\text { acidification }\end{array}$ & 30 \\
\hline & & $\begin{array}{l}\text { In the crude extract, some or little fragments of magnesium } \\
\text { ribbon were mixed and then drop wise concentrated } \\
\text { hydrochloric acid was mixed. }\end{array}$ & Pink vermilion color & 30 \\
\hline & & $\begin{array}{l}\text { To the plant extract add alcohol and then filter paper strips } \\
\text { were dipped in it and then the solution was ammoniated }\end{array}$ & $\begin{array}{l}\text { Change of color of strips } \\
\text { to yellow }\end{array}$ & 31 \\
\hline & & $\begin{array}{l}0.15 \mathrm{~mL} \text { of } 5 \% \mathrm{NaNO}_{2} \text { and } 2 \mathrm{~mL} \text { of distill water was merged } \\
\text { to the plant extract. } 0.15 \mathrm{~mL} \text { of } \mathrm{AlCl}_{3} \text { solution }(10 \%) \text { was } \\
\text { added after } 5 \mathrm{~min} \text { and then for } 5 \mathrm{~min} \text { allows it to stand. Then } \\
\text { mix } 2 \mathrm{~mL} \text { of } \mathrm{NaOH} \text { solution ( } 4 \% \text { ) to the mixture. To make } \\
\text { the total volume up to } 5 \mathrm{~mL} \text { instantly water was mixed, stir } \\
\text { and then for } 15 \mathrm{~min} \text { allow it to stand. }\end{array}$ & Pink color & 31 \\
\hline \multirow[t]{3}{*}{3.} & \multirow[t]{3}{*}{ Phenols } & $\begin{array}{l}\text { The Crude extract was merged with } 2 \mathrm{~mL} \text { of } \mathrm{FeCl}_{3} \text { solution } \\
(2 \%) \text {. }\end{array}$ & Black color & 29 \\
\hline & & $\begin{array}{l}\text { To } 1 \mathrm{~mL} \text { of plant extract, } 4 \mathrm{~mL} \text { of } \mathrm{Na}_{2} \mathrm{CO}_{3} \text { and } 5 \mathrm{~mL} \text { of Folin- } \\
\text { ciocalteu reagent were added. }\end{array}$ & Blue color & 32 \\
\hline & & $\begin{array}{l}\text { Few drops of lead acetate solution (10\%) were merged to the } \\
\text { solution. }\end{array}$ & White precipitates & 33 \\
\hline \multirow[t]{2}{*}{4} & \multirow[t]{2}{*}{ Terpenoids } & $\begin{array}{l}\text { To } 2 \mathrm{~mL} \text { of plant extract, } 2 \mathrm{~mL} \text { of acetic anhydride and 2-3 } \\
\text { drops of concentrated } \mathrm{H}_{2} \mathrm{SO}_{4} \text { was merged. }\end{array}$ & Deep red coloration & 34 \\
\hline & & $\begin{array}{l}2 \mathrm{~mL} \text { of chloroform was dissolved in the crude extract and } \\
\text { evaporated to dryness. Afterwards this was heated for about } \\
2 \text { min with the addition of } 2 \mathrm{~mL} \text { of concentrated } \mathrm{H}_{2} \mathrm{SO}_{4} \text {. }\end{array}$ & Grayish color & 30 \\
\hline \multirow[t]{3}{*}{5} & \multirow[t]{3}{*}{ Saponins } & $5 \mathrm{~mL}$ of distill water was merged to $5 \mathrm{~mL}$ of plant extract. & Heat froth appearance & 34 \\
\hline & & $\begin{array}{l}\text { Some drops of olive oil were merged to the } 5 \mathrm{~mL} \text { extract of } \\
\text { plant. }\end{array}$ & $\begin{array}{l}\text { Formation of the } \\
\text { emulsions }\end{array}$ & 34 \\
\hline & & $\begin{array}{l}\text { Some drops of sodium bicarbonate were merged to } 1 \mathrm{~mL} \\
\text { extract of plant. }\end{array}$ & $\begin{array}{l}\text { Formation of honey comb } \\
\text { like structures }\end{array}$ & $35-36$ \\
\hline 6 & Steroids & $\begin{array}{l}\text { To the } 2 \mathrm{~mL} \text { of extract merged } 2 \mathrm{~mL} \text { of chloroform and } 2 \mathrm{~mL} \\
\text { of } \mathrm{H}_{2} \mathrm{SO}_{4} \text { (conc.). }\end{array}$ & $\begin{array}{l}\text { Reddish brown ring at the } \\
\text { junction indicated }\end{array}$ & 30 \\
\hline 7 & Phytosterols & $\begin{array}{l}5 \mathrm{~mL} \text { chloroform, } 3 \mathrm{~mL} \text { acetic anhydride, few drops of dil. } \\
\text { Acetic acid and some of the drops of concentrated } \mathrm{H}_{2} \mathrm{SO}_{4} \\
\text { were mixed to the } 1 \mathrm{~mL} \text { extract of plant }\end{array}$ & Bluish green coloration & 37 \\
\hline 8 & Phlobatannins & $\begin{array}{l}1 \% \text { solution of } \mathrm{HCl}(2 \mathrm{~mL}) \text { was merged to } 2 \mathrm{~mL} \text { of the plant } \\
\text { extract and then heat. }\end{array}$ & Red precipitates & 34 \\
\hline \multirow[t]{4}{*}{9} & \multirow[t]{4}{*}{ Carbohydrates } & $\begin{array}{l}10 \mathrm{~mL} \text { of distill water, } 2 \mathrm{~mL} \text { of concentrated } \mathrm{H}_{2} \mathrm{SO}_{4}, 2 \text { drops } \\
\text { of ethanolic } \alpha \text {-naphthol }(20 \%) \text { were merged to } 2 \mathrm{~mL} \text { of } \\
\text { extract of plant. }\end{array}$ & $\begin{array}{l}\text { Reddish violet ring at the } \\
\text { junction }\end{array}$ & 30 \\
\hline & & $\begin{array}{l}\text { Fehling B and Fehling A reagents were taken in same } \\
\text { quantities then merged together and } 2 \mathrm{~mL} \text { from this mixture } \\
\text { was merged to unrefined extract and boiled mildly. }\end{array}$ & Brick red precipitates & 30 \\
\hline & & $\begin{array}{l}\text { Unrefined extract was merged to } 2 \mathrm{~mL} \text { of Benedict's reagent } \\
\text { and then boiled. }\end{array}$ & $\begin{array}{l}\text { Reddish } \\
\text { precipitates }\end{array}$ & 30 \\
\hline & & $\begin{array}{l}\text { Unrefined extract was merged to } 2 \mathrm{~mL} \text { of Benedict's reagent } \\
\text { and then boiled. }\end{array}$ & $\begin{array}{l}\text { Dark blue or purple } \\
\text { coloration }\end{array}$ & 30 \\
\hline 10 & Starch & $1 \mathrm{~mL}$ of iodine solution is merged in extract of $1 \mathrm{~mL}$. & Blue coloration & 30 \\
\hline 11 & Glycosides & $\begin{array}{l}\text { To } 2 \mathrm{~mL} \text { of the plant extract, } 2 \mathrm{~mL} \text { of acetic acid and } 2 \mathrm{~mL} \text { of } \\
\text { chloroform was merged. }\end{array}$ & $\begin{array}{l}\text { Color change violet to } \\
\text { blue }\end{array}$ & 30 \\
\hline
\end{tabular}




\begin{tabular}{|c|c|c|c|c|}
\hline & & $\begin{array}{l}\text { To } 1 \mathrm{~mL} \text { of plant extract, } 1 \mathrm{~mL} \text { of } 5 \% \mathrm{FeCl}_{3} \text { solution and } \\
\text { same quantity of acetic acid is used, and then some drops of } \\
\mathrm{H}_{2} \mathrm{SO}_{4} \text { were added to the mixture. }\end{array}$ & Greenish blue color & 38 \\
\hline 12 & $\begin{array}{l}\text { Cardiac } \\
\text { glycosides }\end{array}$ & $\begin{array}{l}1-2 \text { drops of } \mathrm{FeCl}_{3}(2 \%) \text { were added to } 2 \mathrm{~mL} \text { of glacial acetic } \\
\text { acid and then this mixture was mixed with the unrefined } \\
\text { extract. Take another test tube having } 2 \mathrm{~mL} \text { of concentrated } \\
\mathrm{H}_{2} \mathrm{SO}_{4} \text { and then add the above-prepared mixture to this test } \\
\text { tube. }\end{array}$ & $\begin{array}{l}\text { Brown ring at the inter } \\
\text { phase }\end{array}$ & 30 \\
\hline 13 & Coumarins & $\begin{array}{l}\text { To } 2 \mathrm{~mL} \text { of the extract, mix } 3 \mathrm{~mL} \text { of } 10 \% \text { solution of sodium } \\
\text { hydroxide. }\end{array}$ & Yellow color & 34 \\
\hline \multirow[t]{3}{*}{14} & \multirow[t]{3}{*}{ Alkaloids } & $\begin{array}{l}\text { To } 2 \mathrm{~mL} \text { of extract of plant, mix some drops of Hager's } \\
\text { reagent. }\end{array}$ & Yellow precipitates & 34 \\
\hline & & $\begin{array}{l}\text { To } 1 \mathrm{~mL} \text { extract of the plant mix some drops of Dragandrof } \\
\text { reagent }\end{array}$ & Orange brown precipitates & 36 \\
\hline & & $\begin{array}{l}2 \mathrm{~mL} \text { of } \mathrm{HCl}(1 \%) \text { was merged to the unrefined extract and } \\
\text { heated lightly. Then the reagents added to the mixture were } \\
\text { Wagner's and Mayer's reagents }\end{array}$ & $\begin{array}{l}\text { Opaqueness of the end } \\
\text { precipitates }\end{array}$ & 30 \\
\hline \multirow[t]{4}{*}{15} & \multirow[t]{4}{*}{ Proteins } & $\begin{array}{l}\text { To } 1 \mathrm{~mL} \text { of extract of the plant, } 1 \mathrm{~mL} \text { of concentrated } \mathrm{H}_{2} \mathrm{SO}_{4} \\
\text { is mixed. }\end{array}$ & White precipitates & 34 \\
\hline & & $\begin{array}{l}\text { To } 3 \mathrm{~mL} \text { of the plant extract, } 1 \mathrm{~mL} \text { of } 4 \% \mathrm{NaOH} \text { solution } \\
\text { and } 1 \mathrm{~mL} \text { of } 1 \% \text { copper sulphates were mixed. }\end{array}$ & Violet or pink color & 30 \\
\hline & & $\begin{array}{l}\text { Precipitates of white color occurs when the unrefined was } \\
\text { merged with } 2 \mathrm{~mL} \text { of Millon's reagent, and these precipitates } \\
\text { were lightly heated }\end{array}$ & Red Precipitates & 30 \\
\hline & & $\begin{array}{l}\text { A violet color occurred when } 2 \mathrm{~mL} \text { of Ninhydrin }(0.2 \%) \text { was } \\
\text { boiled with unrefined extract }\end{array}$ & Violet color & 30 \\
\hline 16 & Emodin & $\begin{array}{l}2 \mathrm{~mL} \text { of } \mathrm{NH}_{4} \mathrm{OH} \text { and } 3 \mathrm{~mL} \text { benzene was mixed to } 2 \mathrm{~mL} \\
\text { extract of the plant. }\end{array}$ & Red color & 34 \\
\hline 17 & Anthraquinon & $\begin{array}{l}3 \mathrm{~mL} \text { of benzene, } 5 \mathrm{~mL} \text { of } 10 \% \text { solution of } \mathrm{NH}_{3} \text { was mixed } \\
\text { to } 3 \mathrm{~mL} \text { of the plant extract. }\end{array}$ & $\begin{array}{l}\text { Different colors in } \\
\text { ammonical layer like pink, } \\
\text { violet or red }\end{array}$ & 36 \\
\hline \multirow[t]{2}{*}{18} & \multirow[t]{2}{*}{ Anthocyanins } & $2 \mathrm{~mL}$ of $\mathrm{HCl}(2 \mathrm{~N})$ and $\mathrm{NH}_{3}$ was mixed to $2 \mathrm{~mL}$ of extract. & $\begin{array}{l}\text { Pinkish red to bluish violet } \\
\text { coloration }\end{array}$ & \\
\hline & & $\begin{array}{l}\text { To } 1 \mathrm{~mL} \text { extract of the plant, } 1 \mathrm{~mL} \text { of } \mathrm{NaOH}(2 \mathrm{~N}) \text { was mixed } \\
\text { and then heated. }\end{array}$ & Bluish-green colour & 34 \\
\hline 19 & Betacyanin & $\begin{array}{l}\text { To } 1 \mathrm{~mL} \text { extract of the plant, } 1 \mathrm{~mL} \text { of } \mathrm{NaOH}(2 \mathrm{~N}) \text { was mixed } \\
\text { and then heated. }\end{array}$ & Yellow colour & 34 \\
\hline 20 & $\begin{array}{l}\text { Leucoanthocya } \\
\text { nins }\end{array}$ & $5 \mathrm{~mL}$ of isoamyl alcohol was mixed to $5 \mathrm{~mL}$ of plant extract. & Red color in organic layer & 34 \\
\hline 21 & Fixed oils & $\begin{array}{l}\text { Two filter papers were taken and then individually the } \\
\text { extracts were compressed between these filter papers and let } \\
\text { it dry. }\end{array}$ & Oil strain on filter paper & 36 \\
\hline 22 & $\begin{array}{l}\text { Gums and } \\
\text { mucilage }\end{array}$ & $\begin{array}{l}\text { To } 0.1 \mathrm{~mL} \text { of plant extract, } 10 \mathrm{~mL} \text { of distilled water and } 2 \\
\mathrm{~mL} \text { of pure alcohol were mixed with perpetual stirring. }\end{array}$ & White precipitates & 39 \\
\hline
\end{tabular}

\subsection{Biological evaluation}

\subsubsection{Cytotoxicity and cell viability analysis by MTT assay}

The human HepG2 cells were cultured in Dulbecco's Modified Eagle's Medium (DMEM) supplemented with $10 \%$ fetal bovine serum (FBS), 100 units $/ \mathrm{mL}$ penicillin and $100 \mu \mathrm{g} / \mathrm{mL}$ streptomycin and maintained at $37^{\circ} \mathrm{C}$ with $5 \% \mathrm{CO}_{2}$ in a humidified atmosphere. Cells were treated with extracts/compounds dissolved in DMSO with a final DMSO concentration of $0.05 \%$. DMSO-treated cells were used as a control in all the experiments [20]. Cell viability was determined by MTT assay as described previously. Briefly, HepG2 cells were treated with different concentrations of compounds for $48 \mathrm{~h}$. Following treatment, the MTT reagent was added $(500 \mu \mathrm{g} / \mathrm{mL})$ and cells were further incubated at $37^{\circ} \mathrm{C}$ for $4 \mathrm{~h}$. Subsequently $150 \mu \mathrm{L}$ DMSO was added to dissolve formazan crystals and absorbance was measured at $490 \mathrm{~nm}$ in a microplate reader (Thermo Scientific). The percentage of cell viability was calculated [21]. Different extracts of the selected plants were evaluated for their effects against human 
liver cancer lines. It was found that the extract of $H$. rosa sinensis flowers exhibits a strong activity as compared to the other four (Table 3).

\subsubsection{Antioxidant (free radical scavenging) activity using DPPH assay}

In order to perform the antioxidant activity, the stock solution of plant extracts having a concentration of $200 \mathrm{mM}(0.022 \mathrm{~g})$ was prepared. This solution was diluted to $250 \mu \mathrm{g}, 200 \mu \mathrm{g}, 150 \mu \mathrm{g}, 100 \mu \mathrm{g}, 50 \mu \mathrm{g}$, and $25 \mu \mathrm{g}$. DPPH solution of $4 \%$ was prepared by mixing $0.004 \mathrm{~g}$ of DPPH in $100 \mathrm{~mL}$ of methanol. Ascorbic acid was used as a control, which was prepared by mixing $0.0017612 \mathrm{~g}$ into $100 \mathrm{~mL}$ of water having $100-\mu \mathrm{g}$ concentration. In test tubes, $1 \mathrm{~mL}$ of the sample from each diluted solution added and followed by the inclusion of $2 \mathrm{~mL}$ of DPPH solution. In the same way, $1 \mathrm{~mL}$ of the ascorbic acid was added along with $2 \mathrm{~mL}$ of DPPH as control and allowed to stay overnight. The next day, the readings were taken at $517 \mathrm{~nm}$ in triplicate by using a Hitachi U-2900 spectrophotometer and calculated their inhibitory concentration by using formula [22].

$$
A=\frac{\text { Acontrol }- \text { Asample }}{\text { Acontrol }} 100
$$

\section{Results and discussions}

Plants have been widely used for therapeutic purposes to cure diseases at the beginning of human history. According to the WHO report, about $80 \%$ population from rural areas depends upon natural products, herbs, and plants for their necessary health care. Unfortunately, not much attention has been given to investigate the medicinal plants for their useful effects, and constituents with medicinal properties as well as nutraceuticals to discover their health benefits. Therefore, some selected plants were considered to explore their phytochemical, pharmaceutical, and biological characteristics. For that, selected plants were analyzed qualitatively to discover the presence of compounds responsible for their health effects. In addition to qualitative analysis by HPLC to discover the percentage of these compounds, antioxidant and anticancer potential were also investigated.

\subsection{Preliminary qualitative phytochemical analysis}

Preliminary analysis showed the presence of an array of secondary metabolites in the selected plants. Results of qualitative analysis (Table 2) revealed that the targeted plants were rich sources of phytochemicals, particularly flavonoids, phenolic acids, alkaloids, steroids that were responsible for biological activities of plants helping in curing disease, increasing human body immune level and proved as a wound healer. Methanolic extract of $C$. paradaisii seeds has been observed to contain cardiac glycosides, which were not present in peels extract. Moreover, coumarins were found in seed extract while absent in peels extract of $C$. paradaisii. The results of the analysis of M. olifera showed that the phenols, phytosterols, and reducing sugars were present in leave extract while absent in pods and stem extract. Whereas extract of pods and stem (M. olifera) contain alkaloids, absent in leave extract as observed from Table 2. In comparison, $H$. rosa-sinenesus extracts lack of terpenoids, carbohydrates, cardiac glycosides, proteins, emodines, anthraquinones, fixed oils, and gums while others all present (Table 2). Different fractions (Methanol, chloroform, n-hexane, ethyl acetate) of selected plant species (C. sinenesis peels, $C$. paradaisii peels, $H$. rosa sinenesis, $M$. olifera) were found to contain phytoconstituents in different amounts, which were further evaluated by HPLC analysis (quantitative analysis). 
Table 2. Phyto-constituents of selected indigenous plants

\begin{tabular}{|c|c|c|c|c|c|c|c|c|c|c|c|c|}
\hline \multirow[t]{2}{*}{$\mathrm{S} \#$} & \multirow[t]{2}{*}{$\begin{array}{l}\text { Secondary } \\
\text { metabolites }\end{array}$} & \multicolumn{3}{|c|}{ Citrus sinensis peels } & \multicolumn{3}{|c|}{ Citrus paradiasii Peels } & \multirow{2}{*}{$\begin{array}{c}\text { Citrus paradiasii } \\
\text { seeds }\end{array}$} & \multicolumn{3}{|c|}{$\begin{array}{c}\text { Moringa olifera } \\
\text { (Methanol) }\end{array}$} & \multirow{2}{*}{$\begin{array}{c}\text { Hibiscous } \\
\text { rosa sinensis } \\
\text { Flowers } \\
\text { Methanol } \\
\end{array}$} \\
\hline & & $\begin{array}{c}\text { Me- } \\
\text { thanol }\end{array}$ & Ethylacetate & n-hexane & Methanol & Chloroform & n-hexane & & Pods & Stems & Leaves & \\
\hline 1 & Tannins & + & + & + & + & - & - & + & + & + & + & + \\
\hline 2 & Flavonoids & + & + & + & ++ & ++ & - & + & + & + & + & + \\
\hline 3 & Phenols & - & + & + & + & + & - & + & - & - & + & + \\
\hline 4 & Terpenoids & + & + & + & + & - & - & + & - & + & - & + \\
\hline 5 & Saponins & + & + & + & - & - & - & + & + & + & + & - \\
\hline 6 & Steroids & + & + & + & + & + & - & + & - & + & - & + \\
\hline 7 & Phytosterols & - & - & + & - & - & - & + & - & - & + & + \\
\hline 8 & Phlobatannins & - & + & - & - & - & - & - & - & - & - & + \\
\hline 9 & Carbohydrates & + & + & + & - & - & - & - & - & - & - & - \\
\hline 10 & Starch & - & + & - & - & - & - & - & - & - & - & - \\
\hline 11 & Glycosides & + & - & - & - & - & - & - & - & + & - & + \\
\hline 12 & Cardiac glycosides & + & - & - & - & - & - & + & - & - & - & - \\
\hline 13 & Coumarins & + & + & - & - & - & - & + & - & - & - & + \\
\hline 14 & Alkaloids & - & - & - & ++ & + & - & + & + & + & - & + \\
\hline 15 & Proteins & + & + & + & - & - & - & - & - & - & - & - \\
\hline 16 & Emodines & - & - & - & - & - & - & - & - & - & - & - \\
\hline 17 & Anthraquinones & - & - & - & + & - & - & - & - & - & - & - \\
\hline 18 & Anthocyanins & + & - & - & - & - & - & - & - & - & - & + \\
\hline 19 & Betacynins & - & - & - & - & - & - & - & - & - & - & + \\
\hline 20 & Leucoanthocyanins & - & - & - & - & - & - & - & - & - & - & + \\
\hline 21 & Fixed oils & + & + & + & ++ & ++ & - & - & - & - & - & - \\
\hline 22 & Gums \& Mucilage & - & - & - & - & - & - & - & - & - & - & - \\
\hline 23 & Reducing sugars & - & - & - & + & + & - & - & - & + & + & + \\
\hline
\end{tabular}

\subsection{Quantitative phytochemical analysis by HPLC}

Quantitative analysis by HPLC was performed to confirm the percentage of flavonoids and phenolic acids and results are shown in Table 3. Previously, a study of HPLC analysis has been done for the estimation of phenolics and flavonoids in the root and stem of $C$. sinenesis [23] but we selected its peels for HPLC analysis. Table 3 results showed that the methanolic extract of $C$. sinensis peels consists of quercetin, gallic acid, caffeic acid in high quantities than other fractions but $C$. sinensis peels lack of vanillic acid in all fractions. The $\mathrm{m}$-coumaric acid and syringic acid were absent in ethyl acetate fraction, while synaptic acid, caffeic acid, m-coumaric acid, p-coumaric acid, chlorogenic acid, and syringic acid were not detected in n-hexane fraction. A previous report on $C$. sinenesis determined chlorogenic acid, quercetin, rutin, and hydroxybenzoic acid in both stem and root extract, whereas mandalic acid in root extract and phloroglucinol was detected only in stem extract [23]. In M. olifera, pod, stem, and leave extract to contain quercetin and gallic acid but previously Shervington et al. [24] reported that the $M$. olifera species were influenced by geographical changes strongly and resultantly, its chemical constituents (presence, percentage of occurrence) also varies [24]. HPLC results of $H$. rosa-sinensis showed the detection of quercetin, gallic acid, synaptic acid, caffeic acid, p-coumaric acid, and chlorogenic acid in good percentage. In comparison to the previous report [25] that showed the presence of only flavonoids quercetin, rutin, kaempferol, and myricetin in methanolic extract. From Table 3, it was found that vanillic acid was absent in all plant species but $\mathrm{m}$-coumaric acid and syringic acid were absent in all plants except the methanolic fraction of $C$. sinensis peels. Gallic acid and quercetin were present in all fractions of selected plants except the n-hexane fraction of $C$. paradaisii peels, n-hexane fraction of $C$. sinenesis peels have only quercetin $(0.1 \mathrm{ppm})$ and gallic acid $(15.2 \mathrm{ppm})$. By observing HPLC results (Table 3), it was found that n-hexane fraction of $C$. paradaisii peels lack of any flavonoids and phenolic acids. 
Table 3. Results of quantitative phytochemical analysis by HPLC

\begin{tabular}{|c|c|c|c|c|c|c|c|c|c|c|c|c|}
\hline \multirow[t]{2}{*}{ S\# } & \multirow{2}{*}{$\begin{array}{l}\text { Secondary } \\
\text { metabolites }\end{array}$} & \multicolumn{3}{|c|}{ Citrus sinensis peels } & \multicolumn{3}{|c|}{ Citrus paradiasii Peels } & \multirow{2}{*}{$\begin{array}{c}\text { citrus paradaisii } \\
\text { seeds } \\
\text { Methanol (ppm) }\end{array}$} & \multicolumn{3}{|c|}{ Moringa olifera (Methanol) } & \multirow{2}{*}{$\begin{array}{c}\text { Hibiscous rosa } \\
\text { sinensis Flowers } \\
\text { Methanol (ppm) }\end{array}$} \\
\hline & & $\begin{array}{c}\text { Methanol } \\
\text { (ppm) }\end{array}$ & $\begin{array}{c}\text { Ethylacetate } \\
\text { (ppm) }\end{array}$ & $\begin{array}{c}\text { n-hexane } \\
\text { (ppm) }\end{array}$ & $\begin{array}{c}\text { Methanol } \\
\text { (ppm) }\end{array}$ & $\begin{array}{c}\text { Chloroform } \\
\text { (ppm) }\end{array}$ & $\begin{array}{c}\text { n-hexane } \\
\text { (ppm) }\end{array}$ & & $\begin{array}{l}\text { Pods } \\
\text { (ppm) }\end{array}$ & $\begin{array}{l}\text { Stems } \\
(\mathrm{ppm})\end{array}$ & $\begin{array}{l}\text { Leaves } \\
(\mathrm{ppm})\end{array}$ & \\
\hline 1 & Quercetin & 6.0 & 3.99 & 0.1 & 5.94 & 4.48 & Not & 3.48 & 2.84 & 1.98 & 0.549 & 6.03 \\
\hline 2 & Flavonoids & + & + & + & ++ & ++ & - & + & 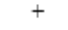 & + & + & + \\
\hline 3 & Gallic acid & 33.24 & 21.04 & 15.2 & 24.06 & 18.24 & - & 5.25 & 3.24 & 0.11 & 1.99 & 11.4 \\
\hline 4 & Synaptic acid & 4.02 & 1.25 & - & 2.45 & - & - & 2.58 & - & - & - & 5.62 \\
\hline 5 & Caffeic acid & 12.56 & 8.26 & - & 10.7 & - & - & 10.63 & - & - & - & 15.4 \\
\hline 6 & Vanillic acid & - & - & - & - & - & - & - & - & - & - & - \\
\hline 7 & m-coumaric acid & 0.125 & - & - & - & - & - & - & - & - & - & - \\
\hline 8 & p-coumaric acid & 5.29 & 3.33 & - & 6.76 & - & - & 3.26 & - & - & - & 35.26 \\
\hline 9 & Chlorogenic acid & 6.32 & 0.236 & - & - & - & - & - & - & - & - & 6.23 \\
\hline 10 & Syringic acid & 0.325 & - & - & - & - & - & - & - & - & - & - \\
\hline
\end{tabular}

\subsection{Anticancer and antioxidant activities}

Anticancer activity results (Table 4 ) revealed that the $M$. olifera showed very low cellular viability against Hep G2 cell lines at a value of 68.0, whereas Lucia et al. (2018) reported 50\% cellular viability against MDCK cellular lines [26]. Another report showed that $M$. olifera leaf extract has a significant inhibitory (80\%) impact on Hep G2 cells [27]. H. rosa-sinenesis showed a cell viability of $132.49 \%$, while a previous report showed its excellent apoptosis induction in breast cancer cell lines [28]. $C$. sinensis was found to exhibit significant cell viability of $142.74 \%$ as compared to other plant extracts due to the presence of phenolics and flavonoids, whereas C. paradaisii showed a cell viability of $82.39 \%$ (Figure 2). Notably, there is no report on the selected citrus species (C. paradaisii and $C$. sinensis). Similarly, the selected plant extracts were evaluated for their antioxidant activity by using DPPH as a free radical using ascorbic acid as a standard. Table 5 showed the percentage of inhibition of each selected plant extracts. Among all extracts, $H$. rosa-sinenesis extract has the lowest $\mathrm{IC}_{50}=0.41 \mathrm{mM}$ value, which makes it a good scavenger followed by $M$. olifera $\left(\mathrm{IC}_{50}=0.42 \mathrm{mM}\right)$, C. paradaisii $\left(\mathrm{IC}_{50}=0.43 \mathrm{mM}\right)$ and $C$. sinenesis $\left(\mathrm{IC}_{50}=0.49 \mathrm{mM}\right)$. This excellent scavenging activity confirms the presence of flavonoids and phenolic acid in an elevated concentration. In comparison to Ayyakkannu, [25] reports, the major factor responsible for excellent antioxidant potential was rutin [25] but in our findings, the main percentage was of p-coumaric acid (Table 3). Antioxidant potential results were in close agreement with HPLC findings, which confirmed that the excellent free radical scavenging potential of $H$. rosa-sinensis was due to a higher concentration of p-coumaric acid and caffeic acid in addition to other flavonoids and phenolic acids.

Table 4. Anti-cancer activity of selected plant extracts against liver cancer cell lines

\begin{tabular}{|c|c|c|c|c|c|c|}
\hline Absorbance & 1 & 2 & 3 & \% viability & \% viability & \% viability \\
\hline Control & 0.904 & 0.842 & 1.034 & 100 & 100 & 100 \\
\hline $\begin{array}{c}\text { Citrus sinenesis } \\
\text { (MeOH) }\end{array}$ & 1.03 & 1.21 & 1.376 & 113.9381 & 143.7054 & 142.74660 \\
\hline $\begin{array}{c}\text { Citrus paradiasii peels } \\
\text { (MeOH) }\end{array}$ & 0.776 & 0.962 & 0.852 & 85.84070 & 114.2517 & 82.3984 \\
\hline Moring olifera & 0.706 & 0.821 & 0.902 & 83.50 & 84.06 & 68.0 \\
\hline Hibiscus rosa sinensis & 1.002 & 1.051 & 1.245 & 120.2 & 148.42 & 132.4951 \\
\hline
\end{tabular}

Table 5. Antioxidant activity of selected plants extracts by using DPPH

\begin{tabular}{|l|c|c|c|c|c|}
\hline Test samples & \multicolumn{5}{|c|}{ Antioxidant activity (Percentage inhibition) } \\
\hline Conc. & $10 \mu \mathrm{g}$ & $25 \mu \mathrm{g}$ & $50 \mu \mathrm{g}$ & $250 \mu \mathrm{g}$ & $\mathrm{IC} 50(\mathrm{mM})$ \\
\hline $\begin{array}{l}\text { Citrus sinenesis } \\
\text { (MeOH) }\end{array}$ & $14 \pm 0.04$ & $21 \pm 0.01$ & $42 \pm 0.006$ & $68 \pm 0.01$ & 0.49 \\
\hline $\begin{array}{l}\text { Citrus paradiasii peels } \\
\text { (MeOH) }\end{array}$ & $11 \pm 0.008$ & $23 \pm 0.004$ & $43 \pm 0.02$ & $66 \pm 0.01$ & 0.43 \\
\hline Moring olifera & $11 \pm 0.0005$ & $34 \pm 0.0003$ & $54 \pm 0.001$ & $62 \pm 0.03$ & 0.42 \\
\hline Hibiscus rosa sinensis & $15 \pm 0.001$ & $36 \pm 0.009$ & $67 \pm 0.006$ & $61 \pm 0.05$ & 0.41 \\
\hline
\end{tabular}




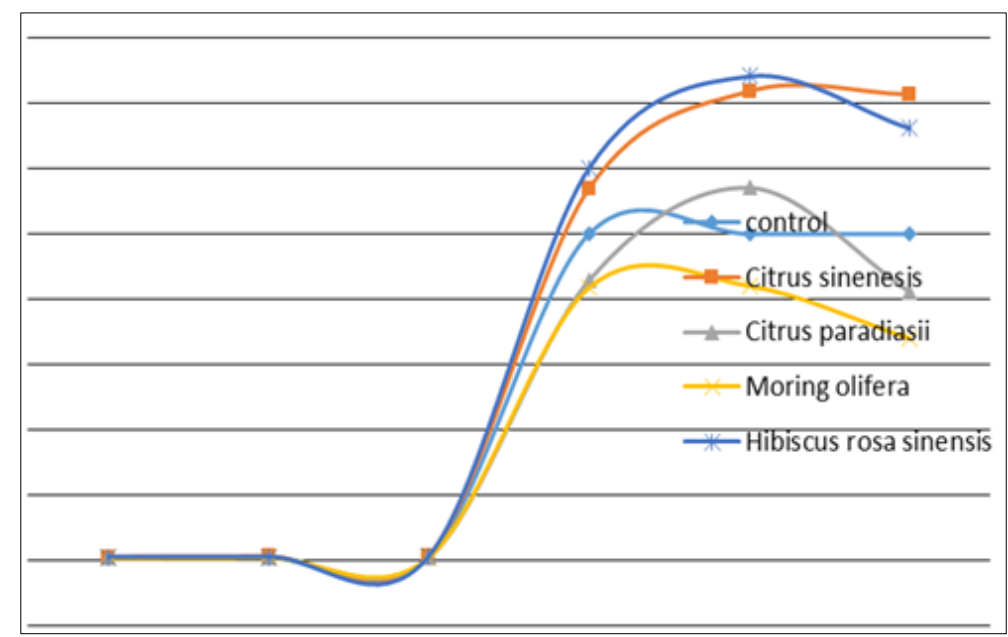

Figure 2. Graph representing the percent viability of cells

\section{Conclusions}

From the above study, it has been concluded that Citrus plants (sinensis and paradasii) are of enormous importance in pharmaceuticals and medicines due to the presence of many important phytoconstituents. The phytochemical analysis of $C$. sinensis peels proves to be very beneficial because of the presence of phytochemicals or bioactive compounds that are useful in various ways. These healing properties were observed due to the presence of tannins, flavonoids, terpenoids, saponins, reducing sugars. H. rosa sinensis has been used in various ways like tea, extract to weight loss, its flower water extract used to cure stomach disorders, skin irritations as anti-aging. Due to its much use as nutraceuticals, when it was phytochemically analyzed, it showed the presence of flavonoids, phenolics, alkaloids. Biological evaluation of the selected plants in different concentrations showed good results. C. sinensis showed the highest $\mathrm{IC}_{50}$ at $0.49 \mathrm{mM}$, while $H$. rosa-sinenesis plant species showed the lowest $\mathrm{IC}_{50}$ at $0.41 \mathrm{mM}$. These results showed that $H$. rosa sinensis has more activity, $C$. sinenesis has lower activity, while the $C$. paradaisii and $M$. olifera have medium activities.

Acknowledgement.The authors were very thankful to the Higher education commission of Pakistan for providing facilities to carry out the studies.

\section{References}

1.I. JOHNSON, New approaches to the role of diet in the prevention of cancers of the alimentary tract., Mutat Res 2004, 511, 9-28.

2.K. JOSHIPURA, A. ASCHERIO, J. MANSON, M. STAMPFER, E. RIMM, F. SPEIZER, C. HENNEKENS, D. SPIEGELMAN AND W. WILLETT, Fruit and vegetable intake in relation to risk of ischemic stroke, JAMA 1999, 282, 1233-1239.

3.K. JOSHIPURA, F. HU, J. MANSON, M. STAMPFER, E. RIMM, F. SPEIZER, G. COLDITZ, A. ASCHERIO, B. ROSNER, D. SPIEGELMAN AND W. WILLETT, The effect of fruit and vegetable intake on risk for coronary heart disease Ann Intern Med, 2001, 134, 1106-1114.

4.E. RIBOLI AND T. NORAT, Epidemiologic evidence of the protective effect of fruit and vegetables on cancer risk., Am J Clin Nutr, 2003, 78, 559S-569S.

5.S. STANNER, J. HUGHES, C. KELLY AND J. BUTTRISS, A review of the epidemiological evidence for the 'antioxidant hypothesis', Public Health Nutr, 2004, 7, 407-422.

6.M. S. VALIATHAN, Healing plants, Current Science, 1998, 75, 1122-1127.

7.A. SARFRAZ, M. JAVEED, M. A. SHAH, G. HUSSAIN, N. SHAFIQ, I. SARFARZ, A. RIAZ, A. SADIQA, R. ZARA, Z. ZAFAR, L. KANWAL, S. D. SARKER AND A. RASUL, Biochanin A: A 
novel Bioactive multifunctional compound from nature Science of the Total Environment, 2020, 722, 112.

8.S. ZAFAR, I. SARFRAZ, A. RASUL, M. A. SHAH, G. HUSSAIN, M. K. ZAHOOR, N. SHAFIQ, A. RIAZ, Z. SELAMOGLU AND S. SARKER, Osthole: A Multifunctional Natural Compound with Potential Anticancer, Antioxidant and Anti-inflammatory Activities, Mini-reviwes in Medicinal chemistry, 2020, 20, 1-19.

9.V. SHARMA, A. SHARMA AND L. KANSAL, The effect of oral administration of Allium sativum extracts on lead nitrate induced toxicity in male mice, Food Chemistry and Toxicology, 2010, 48, 928936.

10.X. LV, S. ZHAO, Z. NING, H. ZENG, Y. SHU, O. TAO, C. XIAO, C. LU AND Y. LIU, Citrus fruits as a treasure trove of active natural metabolites that potentially provide benefits for human health, Chemistry Central Journal, 2015, 9, 2-3.

11.P. M. AJA, N. NWACHUKWU, U. A. IBIAM, I. O. IGWENYI, C. E. C. E. OFFOR AND U. O. ORJI, Chemical Constituents of Moringa oleifera Leaves and Seeds from Abakaliki, Nigeria, American Journal of Phytomedicine and Clinical Therapeutics, 2014, 2, 310-321.

12.S. GOTHAI, K. MUNIANDY, M. A. ZARIN, T. W. SEAN, S. KUMAR, A. M. MUNUSAMY, S. FAKURAZI AND P. ARULSELVAN, Chemical Composition of Moringa oleifera Ethyl Acetate Fraction and Its Biological Activity in Diabetic Human Dermal Fibroblasts, Pharmacogn Mag., 2017, 13, 462-469.

13.V. GUPTA, K. KOHLI, P. GHAIYE, P. BANSAL AND A. LATHER, A pharmacological potentials of Citrus Paradisi - An overview., Int. J. Phytother. Res., 2011, 1, 8-17.

14.L. CASTRO-VAZQUEZ, M. E. ALAÑÓN, V. RODRÍGUEZ-ROBLEDO, M. S. PÉREZ-COELLO, I. H. GUTIERREZ, M. C. DÍAZ-MAROTO, J. JORDÁN, M. F. GALINDO AND M. D. M. ARROYOJIMÉNEZ, In vitro antioxiᄀdant activity of extracts from leaves and flowers from University of MessinaItaly, Oxid. Med. Cell. Longev, 2016, 12, 203-210.

15.I. DA-COSTA-ROCHA, B. BONNLAENDER, H. SIEVERS, I. PISCHEL AND M. HEINRICH, Hibiscus sabdariffa L. Phytochemical and pharmacological Review, Food Chemistry and Toxicology, 2014, 165, 424-443.

16.N. C. CARVALHO, M. J. F. CORREA-ANGELONI, D. D. LEFFA, J. JEVERSON MOREIRA, V. NICOLAU, P. A. AMARAL, A. E. ROSSATTO AND V. M. ANDRADE, Evaluation of the genotoxic and antigenotoxic potential of Melissa officinalis in mice, Genetics and Molecular Biology, 2011, 34, 290-297.

17.A. E. SULIEMAN, S. E. ABDELRAHMAN AND A. M. ABDEL RAHIM, Phytochemical Analysis of Local Spearmint (Mentha spicata) Leaves and Detection of the Antimicrobial Activity of its Oil, Journal of Microbiology Research, 2011, 1, 1-4.

18.R. GUL, S. U. JAN, S. FARIDULLAH, S. SHERANI AND N. JAHAN, Preliminary Phytochemical Screening, Quantitative Analysis of Alkaloids, and Antioxidant Activity of Crude Plant Extracts from Ephedra intermedia Indigenous to Balochistan, Hindawi The scientific World Journal, 2017, 2017, 1-7. 19.K. S. BANU AND D. L.CATHRINE, General Techniques involved in Phytochemical Analysis, International Journal of Advanced Research in Chemical Science, 2015, 2, 25-32.

20.G. FOTAKIS AND J. A. TIMBRELL, In vitro cytotoxicity assays: comparison of LDH, neutral red, MTT and protein assay in hepatoma cell lines following exposure to cadmium chloride, Toxicology letters, 2006, 160, 171-177.

21.A. KAMAL, J. S. REDDY, M. J. RAMAIAH, D. DASTAGIRI, E. V. BHARATHI, M. V. P. SAGAR, S. PUSHPAVALLI, P. RAY AND M. PAL-BHADRA, Design, synthesis and biological evaluation of imidazopyridine/pyrimidine-chalcone derivatives as potential anticancer agents, Medicinal chemistry communication, 2010., 1, 355-360.

22.P. MOLYNEUX, The use of the stable free radical diphenylpicrylhydrazyl (DPPH) for estimating antioxidant activity, Songklanakarin Journal of Science and Technology, 2004, 26, 211-219. 
23.M. ZAHOOR, A. B. SHAH, S. GUL AND S. AMIN, HPLC-UV analysis of antioxidants in Citrus sinensis stem and root extracts, Journal-Chemical Society of Pakistan 2017, 40, 595-601.

24.L. A. SHERVINGTON, B. S. LI, A. A. SHERVINGTON, N. ALPAN, R. PATEL, U. MUTTAKIN AND E. MULLA, A Comparative HPLC Analysis of Myricetin, Quercetin and Kaempferol Flavonoids Isolated From Gambian and Indian Moringa oleifera Leaves, International Journal of Chemistry, 2018, 10, 28-37.

25.P. AYYAKKANNU, A. PURUSHOTHAMAN, P. MEENATCHI, S. S, RAMALINGAM, SUNDARAM AND N. SARAVANAN, Quantification of Total Phenolic Content, HPLC Analysis of Flavonoids and Assessment of Antioxidant and Anti-haemolytic Activities of Hibiscus rosasinensis L. Flowers in vitro, International Journal of Pharma Research and Health Sciences, 2016, 4, 1342-1350. 26.L. ARÉVALO-HÍJAR, M. Á. AGUILAR-LUIS, S. CABALLERO-GARCÍA, N. GONZÁLESSOTO AND J. D. VALLE-MENDOZA, Antibacterial and Cytotoxic Effects of Moringa oleifera (Moringa) and Azadirachta indica (Neem) Methanolic Extracts against Strains of Enterococcus faecalis, International Journal of Dentistry, 2018, 2018, 1-5.

27.I. L. JUNG, J. H. LEE and S. C. KANG, A potential oral anticancer drug candidate, Moringa oleifera leaf extract, induces the apoptosis of human hepatocellular carcinoma cells, Oncology Letter, 2015, 10, 1597-1604.

28.C. NGUYEN, K. BASKARAN, A. PUPULIN, I. RUVINOV, O. ZAITOON, S. GREWAL, B. SCARIA, A. MEHAIDLI, C. VEGH AND S. PANDEY, Hibiscus flower extract selectively induces apoptosis in breast cancer cells and positively interacts with common chemotherapeutic, $B M C$ Complementary and Alternative Medicine, 2019, 19, 1-14.

29.P. TIWARI, B. KUMAR, M. M. KAUR, G. KAUR AND H. KAUR, Phytochemical screening and extraction: A Review, Internationale Pharmaceutica Sciencia, 2011, 1, 98-106.

30.R. N. S. YADAV AND M. AGARWALA, Phytochemical analysis of some medicinal plants, Journal of Phytology, 2011, 3, 10-14.

31.R. S. PAL AND Y. PAL, Pharmacognostic review and phytochemical screening of Centella asiatica Linn,, Journal of Medicinal Plants Studies, 2016, 4, 132-135.

32.S. R. SELVI, R. Z. A. KUMAR AND A. BHASKAR, Phytochemical investigation and in vitro antioxi $\neg$ dant activity of Citrus sinensis peel extract, Der Pharmacia Letter, 2016, 8, 159-165.

33.K. L. SINGH AND G. C. BAG, Phytochemical analysis and determination of total phenolic content in water extracts of three species of Hedychium, International Journal of PharmTech Research, 2013, 5, 1516-1521.

34.M. YADAV, S. CHATTERJI, S. K. GUPTA AND G. WATAL, Preliminary phytochemical screening of six medicinal plants used in traditional medicine, International Journal of Pharmacy and Pharmaceutical Sciences, 2014, 6, 539-542.

35.S. SUMBUL, M. A. AHMAD, M. ASIF, M. AKHTAR AND I. SAUD, Physiochemical and phytochemical standardization of berries of Myrtus communis Linn, Journal of Pharmacy and Bioallied Sciences, 2012, 4, 322-326.

36.P. S. CHEDE, Phytochemical analysis of Citrus sinensis pulp, International Journal of Pharmacognosy and Phytochemical Research, 2013, 4, 221-223.

37.A. Pradnya And C. Alka, Field test for the detection of Phytosterols, International Research Journal of Pharmacy, 2014, 5, 734-736.

38.M. TEJA, B. RAMYA, S. M. REDDY, G. J. SUDHA, B. JANAKI, S. RAMA AND S. A. R. KUMAr, Preliminary phytochemical evaluation of Caesalpinia Sappan Saraca indica, International Journal of Research in Pharmacy and Chemistry, 2016, 6, 140-143.

39.K. S. BANU AND L. CATHERINE, General techniques involved in phytochemical analysis., International Journal of Advanced Research in Chemical Science, 2015, 2, 25-32

$\overline{\text { Manuscript received: } 03.11 .2020}$ 